\title{
MIC and MKC Analysis of Herbal Medicine in Indonesia Against Mycobacterium tuberculosis
}

\author{
Sesilia Rante Pakadang ${ }^{1}$, Maria Hilaria ${ }^{2}$, Sisilia Teresia Rosmala Dewi ${ }^{1}$, Santi Sinala ${ }^{1 * *}$, Jumain ${ }^{1}$
}

Sesilia Rante Pakadang', Maria Hilaria², Sisilia Teresia Rosmala Dewi', Santi Sinala ${ }^{1, *}$, Jumain ${ }^{1}$

'Health Polytechnic of the Makassar Ministry of Health, INDONESIA.

${ }^{2}$ Health Polytechnic of the Kupang Ministry of Health, INDONESIA.

\section{Correspondence}

\section{Santi Sinala}

Health Polytechnic of the Makassar Ministry of Health, INDONESIA

E-mail: santisinala@poltekkes-mks.ac.id History

- Submission Date: 19-03-2021:

- Review completed: 27-05-2021;

- Accepted Date: 01-06-2021.

DOI : 10.5530/pj.2021.13.137

Article Available online

http://www.phcogj.com/v13/i5

\section{Copyright}

(c) 2021 Phcogj.Com. This is an openaccess article distributed under the terms of the Creative Commons Attribution 4.0 International license.

\begin{abstract}
Data shows that the success of the Directly Observed Treatment Shortcourse program(DOTS) in South Sulawesi Province was $74.8 \%$. Causes of failure include standard drug side effects, length of treatment period and Mycobacterium tuberculosis (M.tb) bacterial resistance. The development of new drugs today in addition to synthetic chemical drugs are also natural materials that have the potential as antituberculosis with various mechanisms. The aim of the research is to prove the potential of plants used by the community as tuberculosis drugs empirically based on phytochemical screening extracts, M.tb sensitivity to extracts and determine the MIC (Minimum Inhibitory Concentration) and MKC (Minimum Killing Concentration) values of M.tb. Selection of plant test materials based on survey results and Riskesdas data in 2015. Testing the potential of plant extracts based on the sensitivity of M.tb to the test material in vitro with an incubation period of 7 weeks. Showed 25 plants that have been used empirically as tuberculosis drugs proved to be potential antibacterial M.tb. Phytochemical screening produces flavonoids and tannins in all extracts. Some extracts contain alkaloids, saponins and steroids. Potential tests show that the extract concentration that is effectively used as a tuberculosis drug is: Meniran leaves and miana $100 \mathrm{ppm}$. Banana peel and basil leaves $125 \mathrm{ppm} .150 \mathrm{ppm}$ bangle rhizome. Turmeric rhizome $175 \mathrm{ppm}$. Roselle flowers, soursop leaves and lime 200 ppm. Sandalwood, bitter melon leaves and binahong 225 ppm, Curcuma rhizome, kencur, turmeric and onion tubers, gotu kola leaves, sea lava and papaya 275 ppm. Ginger rhizome, brotowali stem, noni leaf, cloves and mangosteen peel $>275$ ppm. $90 \%$ garlic bulb extract.

Key words: Antituberculosis, MIC, MKC, Potential, Plants.
\end{abstract}

\section{INTRODUCTION}

Tuberculosis is an infectious disease that can attack all levels of the society. According to data and information on Indonesia's Health Profile in 2018, 511,873 cases of tuberculosis were found with 204,394 new cases. Even though all health facilities have implemented the DOTS (Directly Observed Treatment Shortcourse program) strategy to eradicate tuberculosis in the country, however the success of this program is still $80.12 \%{ }^{1}$. Therefore, it can be stated that there are still many patients who failed their treatment. These individuals will continue to be a source of further infection in the community.

Tuberculosis treatment using medicinal plants serves as an alternative and complementary to conventional medicine. These plants are natural assets which are important to the society and play a role in primary health of mankind ${ }^{2}$. Also, the use of traditional medicinal plants in Indonesia has been proven from old manuscripts on lontar leaves (Java), usada (Bali), lontarak pabbura (South Sulawesi), documents of primbon jampi fiber, fiber concocted wu boreh; ang ndalem and reliefs of Borobudur Temple ${ }^{3}$. In fact, the public believes that the side effects of herbal medicines are safer than modern drugs when used with the dose, time and method according to accurate information. The ingredients accuracy determines the herbal medicine effectiveness accuracy of the ingredients ${ }^{4}$. However, the limitation of herbal medicine is that the dosage is not standardized and clinical trials have not been carried out. Therefore, it is necessary to correct the dosage and timing 5 .

Vegetable antimicrobials are an untapped source of medicines and further exploration is currently a necessity. Furthermore, plant-derived antimicrobials have enormous therapeutic potential. Also, these antimicrobials have a long history of providing much needed new therapies ${ }^{6}$. Research data on medicinal plants and herbs in 2012 and 2015, recorded the use of medicinal plants in Indonesia for various diseases including tuberculosis. The data showed that 10 types of plants have been used ${ }^{7}$. Based on previously conducted survey, it was found that 34 parts of 25 types of plants have been used by the community to treat tuberculosis symptoms such as coughing up blood. However, the empirical use of herbal medicine in the community needs to be supported by scientific research, especially to determine the effective concentration for the basis for further dosing.

\section{MATERIALS AND METHODS}

Preparation of test bacteria and test materials

The bacteria used was M.tb H37RV obtained from the Laboratory of Microbiology, Faculty of Medicine, Hasanuddin University. Furthermore, the bacteria were rejuvenated for 4 weeks until M.tb grew to resemble cauliflower on the surface of the LJA media. Subsequently, the bacteria were suspended and diluted equivalent to the Mc Farland 0.5 standard turbidity.

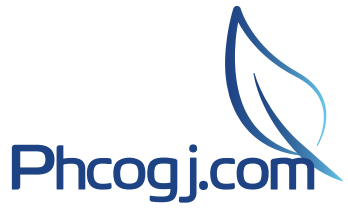

Cite this article: Pakadang SR, Hilaria M, Dewi STR, Sinala S, Jumain. MIC and MKC Analysis of Herbal Medicine in Indonesia Against Mycobacterium tuberculosis. Pharmacogn J. 2021;13(5): 1058-1064. 


\section{Preparation of test materials (plant extracts)}

The plants used were 25 species determined based on the survey results conducted on the community as well as results on medicinal plants and herbs at the Ministry of Health in 2015. The parts and types of tested plants were: rhizomes (turmeric, ginger, ginger, kencur, white turmeric, bangle); tubers (garlic and onion); stems (sandalwood and brotowali); leaves (gotu kola, bitter melon, sea lime, basil, meniran, binahong, papaya, lime, miana, soursop, noni); flowers (cloves and rosella); fruit skins (banana ambon and mangosteen). All simplicia were taken from the provinces of South Sulawesi and East Nusa Tenggara. The location selection was based on the results of previous surveys where the plants were used by the local community empirically.

Each part of the plant was prepared into dry simplicia by chopping to reduce the size and drying at a temperature $<45^{\circ} \mathrm{C}$. Subsequently, each simplicia was further extracted with $96 \%$ ethanol solvent. Also, the extraction method was adapted to the type of simplicia, namely:

Table 1: Results of extract of phytochemical extracts and screening of test materials.

\begin{tabular}{|c|c|c|c|c|c|c|c|c|}
\hline \multirow[b]{2}{*}{ No. } & \multirow{2}{*}{$\begin{array}{l}\text { Name of test material/ } \\
\text { extract/ juice }\end{array}$} & \multirow{2}{*}{$\begin{array}{l}\text { The simplification } \\
\text { of fresh } \\
\text { ingredients (\%) }\end{array}$} & \multirow{2}{*}{$\begin{array}{c}\text { Yield extract } \\
\text { against simplicia } \\
(\%)\end{array}$} & \multicolumn{5}{|c|}{ Phytochemical screening results } \\
\hline & & & & alkaloid & flavonoid & saponin & tannin & steroid \\
\hline 1 & $\begin{array}{l}\text { Turmeric Rhizome (Curcuma } \\
\text { longa L) }\end{array}$ & 19.6 & 5.3 & + & Flavons & - & gallic tannin & + \\
\hline 2 & $\begin{array}{l}\text { Curcuma Rhizome (Curcuma } \\
\text { zanthoriza Roxb) }\end{array}$ & 25.6 & 5.6 & + & Flavons & - & gallic tannin & + \\
\hline 3 & $\begin{array}{l}\text { Ginger Rhizome (Zingiber } \\
\text { officinale Roscoe) }\end{array}$ & 13.3 & 9.2 & - & Flavons & + & galic tannin & + \\
\hline 4 & $\begin{array}{l}\text { Kencur Rhizome } \\
\text { (Kaemferia galanga L) }\end{array}$ & 16.7 & 7.9 & - & Flavons & - & - & + \\
\hline 5 & $\begin{array}{l}\text { White Turmeric Rhizome } \\
\text { (Curcuma zedoaria (Christm.) } \\
\text { Roscoe) }\end{array}$ & 22.85 & 7.85 & + & flavons & - & galic tannin & + \\
\hline 6 & $\begin{array}{l}\text { Rhizome Bangle (Zingiber } \\
\text { casumounar Roxb.) }\end{array}$ & 10.71 & 6.8 & + & Flavons & - & galic tannin & + \\
\hline 7 & $\begin{array}{l}\text { Garlic Bulbs (juice) } \\
\text { (Allium sativum L) }\end{array}$ & Juice $100 \%$ & Juice $100 \%$ & + & Flavons & - & galic tannin & + \\
\hline 8 & Shallot Bulbs (Allium cepa L.) & 7.14 & 3.1 & - & Flavons & - & catechin tannin & + \\
\hline 9 & $\begin{array}{l}\text { Sandalwood Trunk (Santalum } \\
\text { album L.) }\end{array}$ & - & 24.5 & + & Flavons & - & galic tannin & + \\
\hline 10 & $\begin{array}{l}\text { Brotowali stem } \\
\text { (Tinospora crispa (L.) Miers } \\
\text { ex Hoff) }\end{array}$ & 19.51 & 24.46 & + & Flavons & + & catechin tannin & - \\
\hline 11 & $\begin{array}{l}\text { gotu kola leaf (Centella } \\
\text { asiatica }(\mathrm{L}) \mathrm{Urb})\end{array}$ & 18 & 20.34 & - & Flavons & + & catechin tannin & + \\
\hline 12 & $\begin{array}{l}\text { Pare Leaves (Momordica } \\
\text { charantia L) }\end{array}$ & 10.5 & 4.6 & + & Flavons & + & catechin tannin & + \\
\hline 13 & $\begin{array}{l}\text { Sea Bidara leaf (Strychnos } \\
\text { lucida L) }\end{array}$ & - & 7.53 & + & Flavanol & + & catechin tannin & + \\
\hline 14 & $\begin{array}{l}\text { Basil leave (Ocimum } \\
\text { citriodorum Vis.) }\end{array}$ & 24.34 & 35.06 & - & Flavons & - & catechin tannin & + \\
\hline 15 & $\begin{array}{l}\text { Meniran Leaves (Phyllanthus } \\
\text { urinaria L.) }\end{array}$ & 42.8 & 20.4 & - & Flavons & - & galic tannin & + \\
\hline 16 & $\begin{array}{l}\text { Binahong Leaf (Anredera } \\
\text { cordifolia (Ten.) Steenis) }\end{array}$ & 11.2 & 18.8 & + & Flavons & + & catechin tannin & - \\
\hline 17 & $\begin{array}{l}\text { Papaya leaf (Carica papaya } \\
\text { (L)) }\end{array}$ & 16.94 & 12.8 & + & Flavons & - & catechin tannin & + \\
\hline 18 & $\begin{array}{l}\text { Lime Leaves (Citrus } \\
\text { aurantifolia (Christa) Swingle) }\end{array}$ & 41.76 & 4.8 & - & Flavons & - & galic tannin & + \\
\hline 19 & $\begin{array}{l}\text { Miana Leaf (Coleus } \\
\text { scutellarioides (L.) Benth }\end{array}$ & 16.67 & 25.56 & - & Flavons & + & catechin tannin & + \\
\hline 20 & $\begin{array}{l}\text { Soursop leaf (Annona } \\
\text { muricata L.) }\end{array}$ & 45.45 & 10.64 & - & Flavons & - & catechin tannin & - \\
\hline 21 & $\begin{array}{l}\text { Noni Leaf (Morinda citrifolia } \\
\text { L.) }\end{array}$ & 53.3 & 8.98 & + & Flavons & + & - & + \\
\hline 22 & $\begin{array}{l}\text { Cloves (Syzygium aromaticum } \\
\text { (L.) Merrill \& Perry) }\end{array}$ & 42.85 & 18.86 & - & Flavons & - & galic tannin & + \\
\hline 23 & $\begin{array}{l}\text { Rosella flower (Hibiscus } \\
\text { sabdariffa L.) }\end{array}$ & 15.29 & 18.3 & - & Flavanone & - & galic tannin & + \\
\hline 24 & $\begin{array}{l}\text { Ambon Banana Skins (Musa } \\
\text { paradisiaca L.) }\end{array}$ & 41.9 & 5.53 & + & Flavons & + & galic tannin & + \\
\hline 25 & $\begin{array}{l}\text { Mangosteen rind (Garcinia } \\
\text { mangostana L.) }\end{array}$ & 11 & 25.56 & + & Flavons & - & catechin tannin & + \\
\hline
\end{tabular}

+ : positive containing metabolite compounds, - : negative containing metabolite compounds 
Table 2: Results of testing the potential of plant extract test material as an antituberculosis in vitro.

\begin{tabular}{|c|c|c|c|}
\hline No. & Name of test material /extract / juice & MIC & MKC \\
\hline 1 & Turmeric Rhizome (Curcuma longa $\mathrm{L}$ ) & $50 \mathrm{ppm}$ & 175 ppm \\
\hline 2 & Curcuma Rhizome (Curcuma zanthoriza Roxb) & 75 ppm & $275 \mathrm{ppm}$ \\
\hline 3 & Ginger Rhizome (Zingiber officinale Roscoe) & $50 \mathrm{ppm}$ & $>275 \mathrm{ppm}$ \\
\hline 4 & $\begin{array}{l}\text { Kencur Rhizome } \\
\text { (Kaemferia galanga L) }\end{array}$ & $50 \mathrm{ppm}$ & 275 ppm \\
\hline 5 & White Turmeric Rhizome (Curcuma zedoaria (Christm.) Roscoe) & $50 \mathrm{ppm}$ & $275 \mathrm{ppm}$ \\
\hline 6 & Rhizome Bangle (Zingiber casumounar Roxb.) & $50 \mathrm{ppm}$ & $150 \mathrm{ppm}$ \\
\hline 7 & $\begin{array}{l}\text { Garlic Bulbs (juice) } \\
\text { (Allium sativum } \mathrm{L} \text { ) }\end{array}$ & $40 \%$ & $90 \%$ \\
\hline 8 & Shallot Bulbs (Allium cepa L.) & $50 \mathrm{ppm}$ & $275 \mathrm{ppm}$ \\
\hline 9 & Sandalwood Trunk (Santalum album L.) & 50 ppm & 225 ppm \\
\hline 10 & $\begin{array}{l}\text { Brotowali stem } \\
\text { (Tinospora crispa (L.) Miers ex Hoff) }\end{array}$ & $100 \mathrm{ppm}$ & $>275 \mathrm{ppm}$ \\
\hline 11 & gotu kola leaf (Centella asiatica (L) Urb) & $50 \mathrm{ppm}$ & $275 \mathrm{ppm}$ \\
\hline 12 & Pare Leaves (Momordica charantia L) & $50 \mathrm{ppm}$ & $225 \mathrm{ppm}$ \\
\hline 13 & Sea Bidara leaf (Strychnos lucida L) & $50 \mathrm{ppm}$ & $275 \mathrm{ppm}$ \\
\hline 14 & Basil leave (Ocimum citriodorum Vis.) & $50 \mathrm{ppm}$ & $125 \mathrm{ppm}$ \\
\hline 15 & Meniran Leaves (Phyllanthus urinaria L.) & $50 \mathrm{ppm}$ & $100 \mathrm{ppm}$ \\
\hline 16 & Binahong Leaf (Anredera cordifolia (Ten.) Steenis) & $50 \mathrm{ppm}$ & $225 \mathrm{ppm}$ \\
\hline 17 & Papaya leaf (Carica papaya $(\mathrm{L}))$ & $100 \mathrm{ppm}$ & $275 \mathrm{ppm}$ \\
\hline 18 & Lime Leaves (Citrus aurantifolia (Christa) Swingle) & $50 \mathrm{ppm}$ & $200 \mathrm{ppm}$ \\
\hline 19 & Miana Leaf (Coleus scutellarioides (L.) Benth & $50 \mathrm{ppm}$ & $100 \mathrm{ppm}$ \\
\hline 20 & Soursop leaf (Annona muricata L.) & $50 \mathrm{ppm}$ & $200 \mathrm{ppm}$ \\
\hline 21 & Noni Leaf (Morinda citrifolia L.) & $50 \mathrm{ppm}$ & $>275 \mathrm{ppm}$ \\
\hline 22 & Cloves (Syzygium aromaticum (L.) Merrill \& Perry) & 50 ppm & $>275 \mathrm{ppm}$ \\
\hline 23 & Rosella flower (Hibiscus sabdariffa L.) & $50 \mathrm{ppm}$ & $200 \mathrm{ppm}$ \\
\hline 24 & Ambon Banana Skins (Musa paradisiaca L.) & $75 \mathrm{ppm}$ & $125 \mathrm{ppm}$ \\
\hline 25 & Mangosteen rind (Garcinia mangostana L.) & $75 \mathrm{ppm}$ & $>275 \mathrm{ppm}$ \\
\hline
\end{tabular}

ppm : part per million, MIC (minimal inhibitory concentration), MKC (minimal killing concentration)

rhizomes and fruit macerated, while the stem simplicia was refluxed. Maserat results were then evaporated to make the extract thick and ready for use. Each extract was suspended using $\mathrm{Na}$ CMC to make a series of concentrations of test materials, namely: $50 \mathrm{ppm}, 75 \mathrm{ppm}, 100$ ppm, 125 ppm, 150 ppm, 175 ppm, 200 ppm, 225 ppm, 250 ppm and 275 ppm.

\section{Identification of secondary metabolite extracts based on phytochemical screening}

Fresh simplicia was sorted and dried by the appropriate method for the plant type (oven temperature $40-45^{\circ} \mathrm{C}$ ). Meanwhile, dry simplicia was extracted using ethanol solvent based on the appropriate method for the type of simplicia. Phytochemical screening was conducted for thick viscous using solvents suitable for testing alkaloids, flavonoids, saponins, tannins and steroids. Also, Identification of active substances used standard procedures from Materia Medika Indonesia (1996) ${ }^{8}$, Indonesian Herbal Pharmacopoeia $(2011)^{9}$ and Guidelines for Conducting Clinical Trials for Traditional Medicines $(2000)^{10}$.

Alkaloid identification: $\pm 0.5 \mathrm{~g}$ extract was put into a test tube. Then 2 $\mathrm{mL}$ of $70 \%$ ethanol was added and shaken. Subsequently, $5 \mathrm{ml}$ of $2 \mathrm{~N}$ $\mathrm{HCl}$ was added, and heated in a water bath for 5 mins. After cooling (filtered when necessary) a few drops of Mayer's reagent were added. In addition, the samples were observed, whether turbid / sediment formed, positive containing alkaloids.

Flavonoid identification: $\pm 0.5 \mathrm{~g}$ extract was put into a cup and $2 \mathrm{~mL}$ of $70 \%$ ethanol was added and stirred. Subsequently, $0.5 \mathrm{~g}$ of magnesium powder and 3 drops of concentrated $\mathrm{HCl}$ were added. The formation of orange to red indicates the presence of flavons, red to red indicates flavanol, red to purplish red indicates flavanone.
Saponin identification: $\pm 0.5 \mathrm{~g}$ extracts were put into a test tube. Subsequently, $2 \mathrm{~mL}$ of $70 \%$ ethanol was added and stirred. Also, 10 $\mathrm{mL}$ of distilled water was added and stirred, and then allowed to stand for 15-20 mins. The formation of foam indicates the solution contains saponin.

Steroid identification: $\pm 0.5 \mathrm{~g}$ extract was put into a test tube. Subsequently, $2 \mathrm{~mL}$ of $70 \%$ ethanol was added and stirred. Furthermore, $2 \mathrm{~mL}$ of chloroform was added, and $2 \mathrm{~mL}$ of concentrated sulfuric acid was slowly added through the tube wall. The formation of a red ring indicates the presence of steroids.

Tannin identification: $\pm 0.5 \mathrm{~g}$ extract was put into a test tube. Subsequently, $2 \mathrm{~mL}$ of $70 \%$ ethanol was added and stirred. As much as 3 drops of $1 \% \mathrm{FeCl}_{3}$ was added. The appearance of a blackish blue color indicates the presence of galic tannin compound; when the color is dark green, it indicates the presence of catechin tannin compounds.

Testing of MIC and MKC of plant extracts on the sensitivity of M.tb

The media used was Lowenstein Jensen Agar (Merck), which was prepared by mixing LJA with chicken eggs and repeatedly sterilizing it at $121^{\circ} \mathrm{C}$ (LJA media); $85^{\circ} \mathrm{C}$ and $37^{\circ} \mathrm{C}$ (mixture of LJA and eggs). Furthermore, the media were prepared in sterile screw tubes of $5 \mathrm{ml}$ each. Subsequently, Mtb suspension and extract were added (each extract concentration in a separate tube).

\section{RESULTS AND DISCUSSION}

This study examined the potential of 25 simplicia types which are thought to be potential antituberculosis. Determination of test material was based on survey data in South Sulawesi, East Nusa Tenggara, Research data on medicinal plants and herbs in $2012^{11}$ and Research on medicinal 
plants and herbs in $2015^{12}$. The selected plants have been empirically used in the community in various ways. The potential antituberculosis of each plant simplicia needs to be scientifically proven, in order to provide scientific evidence for use in the society. This is as an effort to develop medicinal plants in the community. Meanwhile, challenges in the development of medicinal plants in Indonesia, among others, is due to lack of scientific data regarding results on medicinal plants (types of products and herbal plants). Furthermore, the mechanism of traditional medicine is still questionable and there is lack of training on traditional medicine. Research on scientific evidence from plants that have been empirically used is increasingly being conducted. Also, there is currently an increasing interest in medicinal plants investigation for new antimicrobial discoveries, antioxidants, and other diseases ${ }^{13}$. Even the herbal drug Alizarin (Chinese herbal medicine) has been developed to overcome resistant M.tb, therefore building an effective and efficient antituberculosis therapy ${ }^{14}$.

Antituberculosis potential testing of 25 simplicia types were tested starting from the extraction stage, phytochemical screening, as well as MIC and MKC testing. Extraction of each simplicia was initiated by collecting plants and then sorting into wet simplicia. The wet simplicia was dried in an oven to become dry, and the process was adjusted to the active ingredient. Those containing essential oils should not be dried at high temperature or direct sun (especially for simplicia whose activity is determined by the essential oil content). Furthermore, dry simplicia was extracted by the method and suitable solvent. The extracted product was then evaporated to separate the solvent, hence the extract can no longer contain the solvent. This procedural stage is based on the stages of preparing a good extract ${ }^{15}$. The yield of dried simplicia was calculated for the wet, and the yield of the thick extract obtained was determined. Therefore, the concentration or effective dose can be converted back into plant doses in the community.

The yield obtained from 25 simplicia tested for dry simplicia against wet was $7.14-53.3 \%$. While the yield obtained from thick extracts against dry simplicia was $3.1 \%-35.06 \%$. The difference in dry yield from the wet simplicia obtained can be caused by: differences in the source of extraction, type, plant parts used, method and duration of drying, as well as size of simplicia. In addition to where the dry and rainy seasons grow, it also influences the chemical composition and antibacterial activity of natural materials such as propolis ${ }^{16}$. Also, plant parts such as stems, roots and leaves influence the content of active substances from plants, including the antibacterial activity produced. However, Khanam et. al. (2015) ${ }^{17}$ found that simplicia that was often used by the community such as Tongkat Ali wood sticks was more potential than trying other parts of the plant. The extract yield for dried simplicia also varies which is influenced by: differences in the type of simplicia, the quality, the number of dissolved active substance, extraction method and time. Some research have determined the amount of yields from extracts. Roselle flower samples showed $12.703 \%$ ethanol extract rendamen with a total phenolic content of $0.1853 \%{ }^{18}$. Meanwhile, many factors cause different yields even from the same simplicia. In addition, the size factor and extraction process significantly affect the extracts quality in terms of rendemen amount and active component in the extract ${ }^{19}$.

Phytochemical screening was carried out on all maceration extracts using ethanol as a solvent. The screening results showed variations in the chemical components of each extract. All the tested extracts contained varied secondary metabolite, such as: flavonoids (flavones and flavanols) and tannins (galic and catechins). Some extracts contain alkaloids, saponins, steroids and triterpenoids. All the active substances contained in plant extracts support the function as antibacterial, including antituberculosis. Also, phytochemical screening is important to identify some compounds (active plant ingredients such as alkaloids, tannins, flavonoids, phenols, steroids, saponins and antraquinones) that have the potential to provide pharmacological effects such as antibacterial ${ }^{20,21}$. The antibiotic and antifungal potential of herbs is also determined by the antibacterial properties of plant phytochemical compounds such as alkaloids, terpenoids, polyphenols, quinones and dissolved phytochemicals ${ }^{22,23}$. Meanwhile, the antibacterial mechanism provided by flavonoid compounds is counteracting hydroxyl free radicals, super oxide anions and fat peroxy radicals. Inhibition of nucleic acid synthesis, cytoplasmic membrane function, energy metabolism, inhibition of attachment and formation of bio-films, inhibition of porin in cell membranes, and changes in membrane permeability ${ }^{24}$. The potential of phenol compounds as antibacterial in killing micro-organisms is denaturation of cell proteins. The formation of hydrogen bonds between phenol compounds and proteins results in damage to the structure of bacterial cell proteins that affect cell wall permeability and cytoplasmic membranes. Also, disruption of cell wall permeability and cytoplasmic membrane causes the macromolecular and ionic components in the cell to become unbalanced, resulting in cell lysis. The antibacterial activity of most polyphenols probably depends on the interaction between polyphenols and bacteria cells surface ${ }^{24}$. Tannins are plant poly phenolic compounds that bind to proteins, amino acids, alkaloids and precipitate them known as antimicrobial biomolecules. Furthermore, the antimicrobial activity of plant parts has the potential to affect some Gram positive and negative pathogenic organisms $^{25}$. Also, saponin as an antibacterial works by lowering the surface tension of the bacterial cell wall, hence it damages the cell membrane permeability, leading to lysis, which makes enzymes and proteins to leave the cell. This release of cell contents leads to bacterial cell death. The antibacterial mechanism of saponins is explained by cell walls and membranes that damage the saponin potential, which is determined by measuring PPA levels and dissolved protein ${ }^{26,27}$. Alkaloid compounds can interfere with the constituent components of peptidoglycan in bacterial cell walls, hence they are incompletely formed which tend to cause cell death. Furthermore, alkaloids inhibit DNA synthesis by inhibiting the enzyme topoisomerase bacterial cells ${ }^{28,29}$. Alkaloids exhibit antibacterial activity as well as inhibit the transport of ATP compounds which depend on the cell membrane. These alkaloids can serve as potential compounds that can act as lead compounds for the development of plant-based antibacterials and / or their auxiliary ${ }^{30}$. Meanwhile, potential steroids as an antibacterial due to sensitivity of cell lipid membranes to steroid components results in liposomes leakage. Steroids are lipophilic compounds, therefore they can interact with cell phospholipid membranes that are permeable to lipophilic compounds. This interaction causes morphology of brittle cell membranes and lysis ${ }^{26,31}$. In addition, active ingredients combination of each extract provides an antibacterial effect of tuberculosis with various mechanisms of action.

The viscous extract obtained was subsequently prepared into a test material. Furthermore, extract dilution was done to test the minimum concentration of each extract that has antituberculosis potential. The test dose provided for testing was $50-275 \mathrm{ppm}$, and the test dose determination was based on several previous tests, including: Garmana et al $(2011)^{32}$, Pakadang SR $(2014)^{33}$ which found that an effective dose of ethanol extract of miana leaves as an antituberculosis in vitro was 100-200 ppm.

The results of testing antituberculosis potential of 25 types of plant extracts showed varying results. Also, MIC observation (minimal inhibitory concentration) was done at the 4 th incubation week. Meanwhile, the reason for establishing MKC (minimum killing concentration) was because in these observations, the M.tb bacterium has grown under negative control (which contains media, aqua pro injection and culture of M.tb ). When the M.tb has grown while in the culture of the test material and positive control does not grow, it can be stated that there has been a bacterial growth inhibition. The 
observation of each extract showed that the MIC value varies from 50 ppm, $75 \mathrm{ppm}, 100 \mathrm{ppm}$ and $125 \mathrm{ppm}$. Furthermore, MIC observations were determined after 7 incubation weeks according to the period of 4-8 weeks M.tb growth. These observations showed that the KBM value of the extract varied from $100 \mathrm{ppm}$ to $275 \mathrm{ppm}$, and there were even 5 extract test materials set $>275 \mathrm{ppm}$. This is because at the last observation (after weeks) at $275 \mathrm{ppm}$ treatment of ginger rhizome extract, clove flowers, brotowali stems, noni leaves and mangosteen rind found a growth colony of M.tb (white like a cauliflower). However, the test results showed that all extracts tested as potential antituberculosis in vitro could at least inhibit M.tb growth. Also, the comparative (positive control) in this study were standard antituberculosis drugs such as izoniasid, rifampicin, streptomycin (all of which are bacteriocidal) and ethambutol which are bacteriostatic. This study showed that the use of streptomycin was most effective because at a dose of $50 \mathrm{ppm}$, it was MKC (minimal kill concentration). The in vitro antituberculosis potential test results are quite promising and in line with previous studies. Ramadhani $(2015)^{34}$ found that brotowali kills M. tb with KBM less than $100 \mathrm{mg} / \mathrm{mL}$. Furthermore, ethanol extract of garlic has an antibacterial effect against M.tb strain H37RV with a minimum killing rate of $2 \%$ and an antibacterial effect against Multidrug Resistant M.tb with a minimum killing rate of $4 \%^{35}$. Also, natural mangosteen skin decoction has the potential to increase neutrophil microbicides activity and can act as antibacterial ${ }^{36}$. The advantages of using herbs as antituberculosis are based on the plant nature. Plants function as antibacterial, immunostimulant, potentiation (supporting the effectiveness of the work of standard drugs), preventing side effects of conventional antituberculosis drugs (standard drugs). Furthermore, it alleviates the symptoms and manifestations of tuberculosis such as coughing. The effect of antibacterial potentiation was demonstrated by Ramayati et al. (2013) which reported that forest kedondong extract combined with rifampicin increased the antibacterial effectiveness of rifampicin against M.tb isolates in vitro.

\section{CONCLUSION}

Phytochemical screening produced flavonoids and tannins in 25 types of extracts, and some contain alkaloids, saponins and steroids. Potential tests showed that the extract concentrations effectively used as a tuberculosis drug are: Meniran leaves and miana $100 \mathrm{ppm}$, banana peel and basil leaves $125 \mathrm{ppm}, 150 \mathrm{ppm}$ bangle rhizome, turmeric rhizome 175 ppm, roselle flowers, soursop leaves and lime 200 ppm. Others include sandalwood, bitter melon leaves and binahong 225 ppm, curcuma rhizome, kencur, turmeric and onion tubers, gotu kola leaves, sea lava and papaya $275 \mathrm{ppm}$, ginger rhizome, brotowali stem, noni leaf, ambon banana and mangosteen peel $>275 \mathrm{ppm}$, as well as $90 \%$ garlic bulb extract.

\section{AUTHORS CONTRIBUTIONS}

All authors contributed equally in this study, and it was in compliance with journal authorship policy. Sesilia Rante Pakadang as main authors, and the others (Maria Hilarria, Sisilia Teresia Rosmala Dewi, Santi Sinala and Jumain) were co-authors which helped in every step. Then Santi Sinala as corespondent author.

\section{CONFLICTS OF INTEREST}

Declared none.

\section{REFERENCES}

1. Ministry of Health. Research on Medicinal and Jamu Plants, National Report on Exploration of Local Knowledge of Ethnomedicine and Community-Based Medicinal Plants in Indonesia, Indonesian Center for Research and Development of Traditional Medicinal and Medicinal Plants, Jakarta, 2016.
2. Nandini G, Gopenath Ts, Nagalambika Prasad, Murugesan Karthikeyan, Ashok Gnanasekaran, Ranjith Ms, Pradeep Palanisamy, Kanthesh M Basalingappa. Phytochemical Analysis and Antioxidant Properties Of Leaf Extracts Of Carica papaya. Asian J Pharm Clin Res, 2020;11, 58-62.

3. Badrunasar A, Santoso Hb. Tumbuhan Liar Berkhasiat Obat. Penerbit Forda Press Bogor Jawa Barat. 2016.

4. Lusia, ORKS. Pemanfaatan Ob.at Tradisional dengan Pertimbangan Manfaat dan Keamanannya. Majalah IImu Kefarmasian, 2016;1:0107.

5. Harsini, Widjijono. Penggunaan Herbal Di Bidang Kedokteran Gigi. Majalah Kedokteran Gigi 2008:1.

6. Janaki A., Kaleena P. K, Elumalai D., Hemalatha P., Babu M., Velu K., Sudha Ravi. Phytochemical Screening, Antioxidant and Antibacterial Activities Of Millingtonia hortensis (L). International Journal Of Current Pharmaceutical Research 2017;5.

7. Ministry of Health of the Republic of Indonesia, Indonesia Health Data Profiles for 2019 Directorate General of PP and PL. Ministry of Health of the Republic of Indonesia 2019.

8. Depkes RI. Materia Medika VI. Directorate of Drug and Food Control. Jakarta. 1995;16-20.

9. Ministry of Health of the Republic of Indonesia. Indonesian Herbal Pharmacopoeia Supplements. Directorate of Traditional Medicine Supervision. Jakarta.2011

10. Ministry of Health of the Republic of Indonesia. Guidelines for Conducting Clinical Trials for Traditional Medicines. Directorate of Traditional Medicine Supervision. Jakarta. 2000; 27-33.

11. Ministry of Health of the Republic of Indonesia. Research on medicinal plants and herbs National Community Based Exploration Report on Ethnomedicin and Medicinal Plants in Indonesia. Ministry of Health of the Republic of Indonesia. Health Research and Development Agency. Jakarta. 2013.

12. Ministry of Health of the Republic of Indonesia. National Report on Special Research on Local Knowledge Exploration of Ethnomedicin and Community-Based Medicinal Plants in Indonesia. Ministry of Health of the Republic of Indonesia. Health Research and Development Agency Research and Development Center for Medicinal and Traditional Medicinal Plants. Jakarta.2016.

13. Alshawsh, M., Abdulla, M., Ismail, S., Amin, Z. Free Radical Scavenging, Antimicrobial and Immunomodulatory Activities of Orthosiphon stamineus. Journal of Molecules 2012; 5385-5395.

14. Zhu M., Zhu L. The research progress ini drug resistant mechanisms of Mycobacterium tuberculosis and its L-form and Antibacterial Effect of Alizarin. Chinese Journal of Microecology. 2013;01.

15. Ministry of Health of the Republic of Indonesia. Guidelines for Extract Based Technology. Directorate of Traditional Medicine Supervision. Jakarta. 2013.

16. Neto M.S.R., Tintino S.R., da Silva A.R.P., do SocorroCosta M., Boligon A.A., Matias E.F.F., Balbino V.Q., Menezes I.R.A. Seasonal Variation of Brazilian Red Propolis: Antibacterial Activity, Synergistic Effect and Phytochemical Screening. Food and Chemical Toxicology September 2017;572-580.

17. Khanam Z., Chew SW., HaqBhat IUI., Phytochemical screening $n$ antimicrobial activity of root and stem extracts of wild Eurycoma longifolia Jack (Tongkat Ali). Journal of King Saud University. Science 2015;1;23-30.

18. Sam S, Malik A, Handayani S, Determination of total phenolic levels from ethanol extracts of red rosella flowers (Hibiscus sabdariffa L.) using UV-Vis spectrophotometry 2016;3:2.

19. Sembiring and Suhirman, Effect of Drying Methods and Extraction Techniques on the Quality of Simplisia and Meniran Extracts, Prosiding seminar Teknologi Pertanian, 2014. 
20. Nwachukwu M.I., Duru M.K.C., Nwachukwu I.O., Obasi C.C, Uzoechi A.U., Ezenwa C.E. Anumodu C.K. In-vitro Phytochemical Characterization and Antibacterial Activity of Newbouldia laevis (boundary tree) on Escherichia coli and Staphylococcus aureus. Asian Journal of Microbiology and Biotechnology 2017;2: 30-36.

21. Enerijiofi K.E and Isola O.B. Preliminary Phytochemical screening and invitro antibacterial activities of aqueous and ethanol extracts of Ageratum conyzoides L. Leaf, Stem, Flower and Root on some Bacterial isolates associated with Diarrhoea Nig. J. Pure \& Appl. Sci. 2019;32:2.

22. Setzer M.S., Rad J.S., Setzer W.N. The Search for Herbal Antibiotics: An In-Silico Investigation of Antibacterial Phytochemicals. Journals Antibiotics. 2016;3:30.

23. Naveen K.C., Srikumar R, Swathi S, Chidambaram R, Muthukrishnan G, Prabhakar R.E., Phytochemical analysis and antifungal activity of Ganoderma lucidum. Indian Journal of Public Health Research \& Development. 2018;9(12):130-135.

24. Chibane L.B., Forquet P., Clement Y., Akkari L.L., Oulahal N., Degraeve P., Borges C., Antibacterial Properties of Polyphenols: Characterization and QSAR (Quantitative Structure-Activity Relationship) Models. Front Microbiol. 2019;10: 829.

25. Kurkehar J.V. Tannins - antimicrobial chemical components. Project: Paper publication 2016.

26. Madduluri S., Rao K.B., Sitaram B. In Vitro Evaluation of Antibacterial Activity of Five Indegenous Plants Extract Against Five Bacterial Pathogens of Human. International Journal of Pharmacy and Pharmaceutical Sciences.2013:5(4): 679-684.

27. Khan M.I., Ahhmed A., Shin J.H., Baek J.S, Kim M.Y., Kim J.D.Green Tea Seed Isolated Saponins Exerts Antibacterial Effects against Various Strains of Gram Positive and Gram Negative Bacteria, a Comprehensive Study In Vitro and In Vivo. Hindawi. EvidenceBased Complementary and Alternative Medicine : 2018.
28. Darsana I., Besung I., Mahatmi H. Potential of Binahong (Anredera cordifolia (Tenore) Steenis) Leaves in Inhibiting the Growth of Escherichia coli Bacteria by In Vitro. Indonesia Medicus Veterinus 2012.

29. Karou D. Dan Savadogo A Antibacterial activity of alkaloids from Sida acuta. African Journal of Biotechnology. 2005.4:1452-1457.

30. Mabhiza D., Chitemerere T., Mukanganyama S. Research Article Antibacterial Properties of Alkaloid Extracts from Callistemon citrinus and Vernonia adoensis against Staphylococcus aureus and Pseudomonas aeruginosa. Hindawi Publishing Corporation International Journal of Medicinal Chemistry 2016.

31. Ahmed and Bahar. Chemistry Of Natural Products. New Delhi:Department of Pharmaceutical Chemistry Faculty of Science Jamia Hamdard. India. 2007.

32. Garmana AN, Sukandar1 EY, Fidrianny I. Test Activity of extracts of several plants against Mycobacterium tuberculosis strain sensitive and resistant, Acta Pharmaceutica Indonesia 2011;3:4.

33. Pakadang SR., The sensitivity of M. tb to the Ethanol Extract of Miana Leaves (Coleus scutellarioides (L.) Benth). Jurnal Farmasi dan Bahan Alam 2014;2:2

34. Ramadhani I. Antituberculosis activity of fraction and ethyl acetate extracts of brotowali (Tinospora crispa (L.) miers) stem in vitro, skripsi, 2015

35. Ramsif Y.B., Rizki L.P., Nurrokhman dan Rintiswati N. Garlic (Allium sativum) Activity Against Mycobacterium tuberculosis and Multidrug Resistant Mycobacterium Tuberculosis, Gadjah Mada University 2012

36. Sakinah AN, Amin MN, Purwanto, Potential of Natural Mangosteen Skin (Garcinia mangostana Linn) Decoction to Increase Neutrophil Cell Microbicidal Activity against Streptococcus mutans, Jurnal Pustaka Kesehatan 2015:3:1.

\section{GRAPHICAL ABSTRACT}

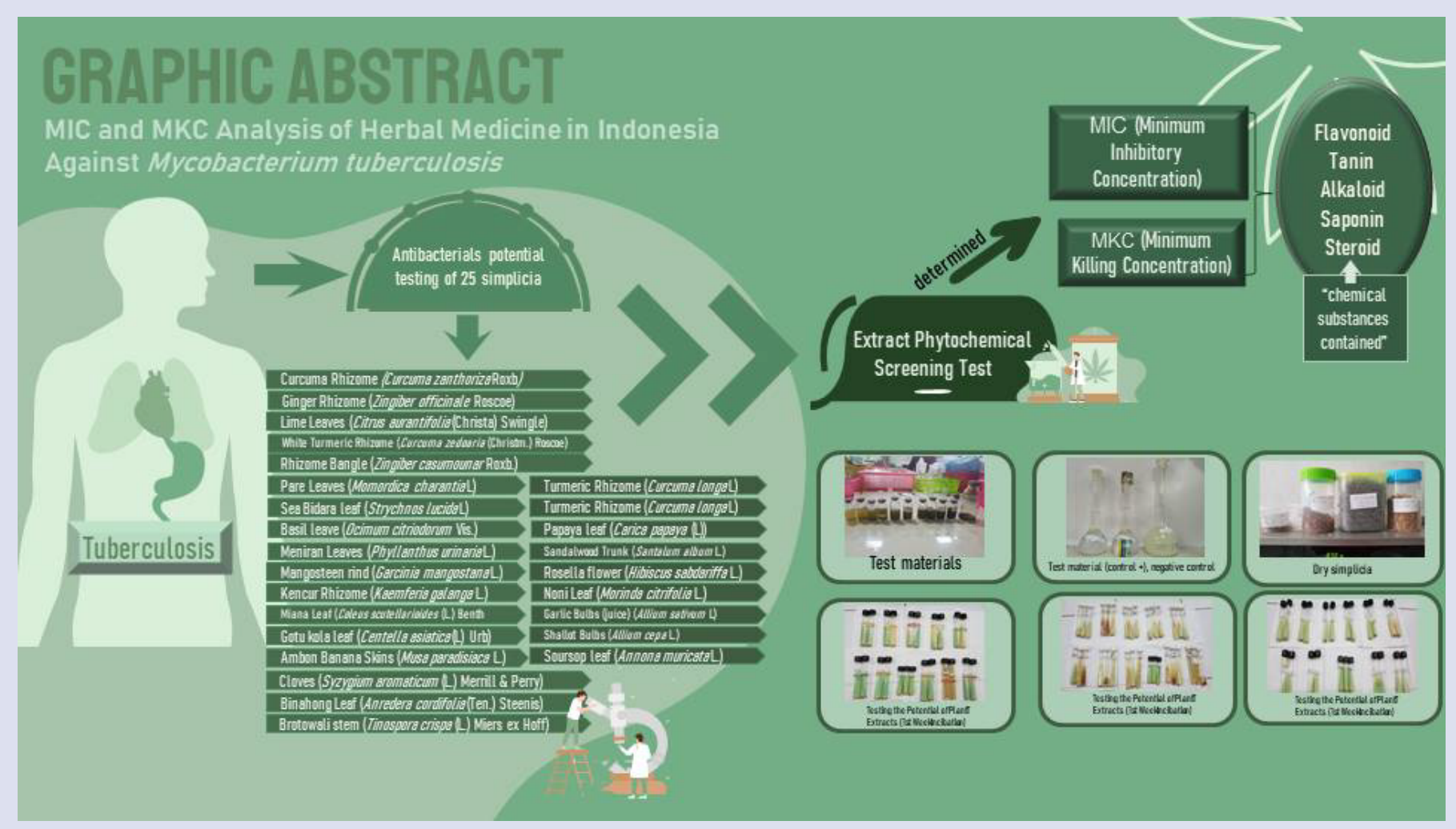




\section{ABOUT AUTHORS}

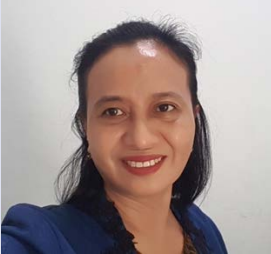

Dr. Sesilia Rante Pakadang, M.Si, Apt was born in Sinjai, September 22, 1969. She studied from bachelor to master at Hasanuddin University. Doctoral education is completed at Airlangga University. Have expertise in the field of Microbiology. Now as a permanent lecturer in the Department of Pharmacy Health Polytechnic Makassar of Ministry Health Republic of Indonesia. The research focuses on traditional medicine as it is today, which is knowing more about the efficacy of Miana Plant. Active as a researcher and has published many articles.

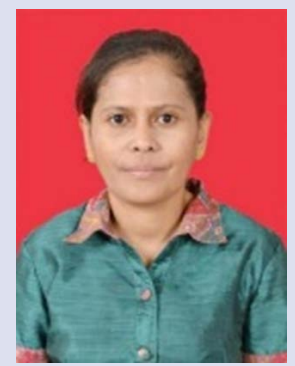

Maria Hilaria is a lecturer in Pharmacy Prodi of Health Polytechnic of Kupang, East Nusa Tenggara, Indonesia. She is a master of pharmacy graduated from the University of Setya Budi, Surakarta. She is also a researcher at the P3T Center of the East Nusa Tenggara Health Service who is actively conducting research on medicinal plants. She is also a Member of the Indonesian Pharmacists Association.

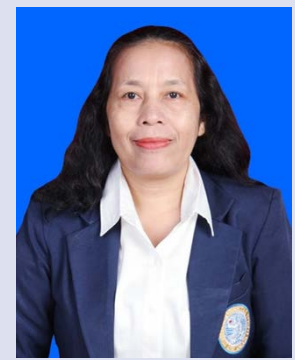

Dr. Sisilia Teresia Rosmala Dewi, M.Kes, Apt was born Kumba, October, 03, 1970. Doctoral education is completed at Airlangga University. A lecturer and researcher from East Nusa Tenggara. Her current research is the development of traditional medicine, one of the plants from where she was born, which is used by the public as an anti-breast cancer. Active as a lecturer in the Department of Pharmacy especially Pharmacology, Health Polytechnic Makassar of Ministry Health Republic of Indonesia. Has produced several publications and books.

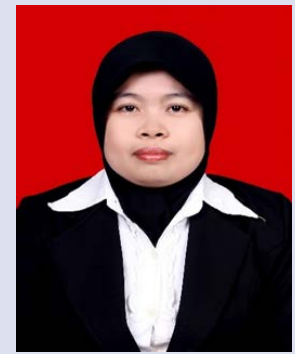

Santi Sinala, S.Si, M.Si., Apt, was born in Palopo, September 28, 1983. Currently a permanent lecturer in the Department of Pharmacy, Health Polytechnic Makassar of Ministry Health Republic of Indonesia, and teaches several courses in the fields of Pharmacognition and Phytochemistry and Physics Pharmacy. The author is active as a researcher in the field of Pharmacy and productively produces as many as 11 scientific articles that have been journalized. Has produced Phytochemistry textbook, Physics Pharmacy Module, Physics Practicum Guide that has been in IPR right. Active as an oral speaker at two international conferences.

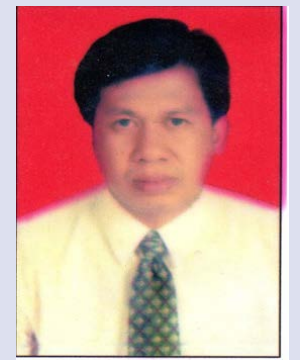

Drs. Jumain, M.Kes, Apt, was born in Lampa, November 16, 1963. A senior lecturer in pharmacology in the Department of Pharmacy, Health Polytechnic Makassar of Ministry Health Republic of Indonesia. He is active as a researcher in the pharmacology of traditional Indonesian medicinal plants and has published many articles in several national journals. In 2009 as outstanding lecturer of national level in the Ministry of Health Republic of Indonesia.

Cite this article: Pakadang SR, Hilaria M, Dewi STR, Sinala S, Jumain. MIC and MKC Analysis of Herbal Medicine in Indonesia Against Mycobacterium tuberculosis. Pharmacogn J. 2021;13(5): 1058-1064. 